\title{
Work and Inter-subjectivity: a theoretical reflection on its dialectics in the field of health and nursing
}

\author{
Brígida Gimenez Carvalho ${ }^{1}$ \\ Marina Peduzzi \\ Edir Nei Teixeira Mandú ${ }^{3}$ \\ José Ricardo de Carvalho Mesquita Ayres ${ }^{4}$
}

This theoretical reflection intends to show the inter-subjective relationship that takes place in health and nursing practices under the following theoretical perspectives: Institutional Analysis, Psychodynamics of Labor and the Theory of Communicative Action, with an emphasis on the latter. Linking these concepts to the Marxist approach to work in the field of health emerges from recognizing the need for its continuous reconstruction -in this case, with a view to understand the interaction and communication intrinsic to work in action. The theory of Communicative Action seeks to consider these two inextricable dimensions: work as productive action and as interaction. The first corresponds to instrumental action based on technical rules with a production-guided rationale. The second refers to the interaction that takes place as communicative action and seeks understanding among subjects. We assume that adopting this theoretical perspective in the analysis of health and nursing practices opens new possibilities for clarifying its social and historical process and inter-subjective connections.

Descriptors: Work; Interpersonal Relations; Health; Nursing.

\footnotetext{
${ }^{1}$ RN, Doctoral student in Nursing Management, Escola de Enfermagem, Universidade de São Paulo, SP, Brazil. Assistant Professor, Departamento de Saúde Coletiva, Centro de Ciências da Saúde, Universidade Estadual de Londrina, PR, Brazil. E-mail: brigidagimenez@gmail.com.

${ }^{2}$ RN, Free Lecturer, Associate Professor, Escola de Enfermagem, Universidade de São Paulo, SP, Brazil. E-mail: marinape@usp.br.

${ }^{3}$ RN, Free Lecturer, Associate Professor, Departamento de Enfermagem, Universidade Federal de Mato Grosso, Cuiabá, MT, Brazil. E-mail: enmandu@terra.com.br.

${ }^{4}$ Physician, Free Lecturer, Associate Professor, Faculdade de Medicina, Universidade de São Paulo, SP, Brazil. E-mail: jrcayres@usp.br.
}

Corresponding Author:

Brígida Gimenez Carvalho

Universidade Estadual de Londrina. Centro de Ciências da Saúde

Departamento de Saúde Coletiva

Av. Robert Koch, 60

Vila Operária

CEP: 86039-440, Londrina, PR

E-mail: brigidagimenez@gmail.com 


\title{
Trabalho e intersubjetividade: reflexão teórica sobre sua dialética no campo da saúde e enfermagem
}

Esta reflexão teórica objetiva evidenciar a relação intersubjetiva presente no trabalho em saúde e enfermagem sob o olhar das seguintes vertentes teóricas: Análise Institucional; Psicodinâmica do Trabalho e Teoria do Agir Comunicativo, com aprofundamento da última. A articulação desses referenciais à abordagem marxiana do trabalho em saúde parte do reconhecimento da necessidade de sua contínua reconstrução neste caso, no sentido da apreensão da interação e comunicação intrínsecas ao trabalho em ato. A Teoria do Agir Comunicativo busca considerar essas duas inextricáveis dimensões: trabalho como ação produtiva e como interação. A primeira corresponde à ação instrumental baseada em regras técnicas e com uma racionalidade dirigida à produção. A segunda refere-se à interação realizada como ação comunicativa visando o entendimento entre sujeitos. Assume-se aqui que a adoção dessa perspectiva teórica na análise das práticas em saúde e enfermagem abre novas possibilidades de elucidação de suas conexões sociais, históricas, processuais e intersubjetivas.

Descritores: Trabalho; Relações Interpessoais; Saúde; Enfermagem.

\section{Trabajo e intersubjetividad: ponderación teorética sobre su dialéctica en el campo de la salud y enfermería}

\begin{abstract}
Esta ponderación teorética objetiva evidenciar la relación intersubjetiva presente en el trabajo en salud y enfermería bajo la mirada de las siguientes vertientes teoréticas: Análisis Institucional; Psicodinámica del Trabajo y Teoría de la Acción Comunicativa, con profundización de la última. La articulación de eses referenciales al abordaje marxiana del trabajo en salud parte del reconocimiento de la necesidad de su continuada reconstrucción - en este caso, en el sentido de la aprehensión de la interacción y comunicación intrínsecas al trabajo en acto. La Teoría de la Acción Comunicativa busca considerar ésas dos inextricables dimensiones: trabajo como acción productiva y como interacción. La primera corresponde a la acción instrumental basada en reglas técnicas y con una racionalidad dirigida a la producción. La segunda se refiere a la interacción realizada como acción comunicativa visando el entendimiento entre sujetos. Se asume aquí que la adopción de esa perspectiva teorética en el análisis de las prácticas en salud y enfermería abre nuevas posibilidades de aclaración de sus conexiones sociales, históricas, procesales e intersubjetivas.
\end{abstract}

Descriptores: Trabajo; Relaciones Interpersonales; Salud; Enfermería.

\section{Introduction}

At present there is important work in the theory of the organization and management of labor ${ }^{(1-3)}$ and specifically in regard to the health field(4-9). There are divergences among authors who discuss labor in contemporary society. They mainly disagree about the centrality and explanatory potential of the Marxist analysis in understanding social reality, especially given its characteristics of economic production and labor in the universe of the human praxis.
The debate around the reconstruction of labor requires that the Marxist category 'labor' be kept as a theoretical-analytical resource but be reconstructed in aspects that permit incorporating new conceptual inputs in a productive manner so as to follow historical changes that occur in the context of labor itself.

The category 'labor' in the field of health, especially in its procedural dimension, needs to be carefully applied because essential elements of the work process in health 
were not considered by Marx in his original work on the subject such as: agents and interaction at work, microsocial aspects of labor, and the objectivity-subjectivity relation that is present within labor relationships. The need to reconstruct Marx's theory, consistent with the historicity of its assumptions, is observed in the analyses of authors who depart from a broad conception of health and focus on dynamic and relational aspects and the participation of subjects themselves in the reconstruction of health practices ${ }^{(4,6-10)}$. That is, the importance of the Marxist category 'labor' to understanding social connections and the historical transformation in health practices is asserted, though it is added to other theoretical categories that clarify procedural and intersubjective dimensions of these practices.

Considering such a need, we discuss in this paper the work-interaction interface, aiming to show the intersubjective relationship that occurs in health and nursing practice and indicate some possibilities for its analysis based on some contemporary theoretical perspectives, highlighting the contributions of the Theory of Communicative Action.

Reflection upon this is enabled by five literature reviews addressing labor in health and nursing in Brazil: Burlandy and Bodstein ${ }^{(11)}$; Almeida, Mishima and Peduzzi(12); Minayo-Gomez and Thedim-Costa(13); Ramos, Bertoncini, Machado, Flor, Pires, Gelbcke(14); Mandú, Peduzzi, Carvalho and Silva(15). These studies allow for the identification of two aspects that jointly ground this manuscript:

- the inflection of studies exclusively based on the Marxist category 'labor' through the inclusion of an analysis of subjectivity-inter-subjectivity in health and nursing care;

- the importance of three theoretical strands in the approach of the work-interaction interface present in the manuscript: Institutional Analysis, Psychodynamics of Labor, and Communicative Action.

Critical analysis was employed, including a problematization of the theme, interpretative reading of related bibliography and our own view conceptually based on the subject.

\section{Characteristics of health work}

In Marx's view, the work process is the human activity in which workers take physical and mental energies and use instruments to transform a given object into a product or outcome, which can be characterized as material goods or services. The product of work is a perceived need, idealized before its production, that is, it results from an intention, always of a social nature. The three elements composing the work process - activity appropriate to an end, that is, work guided by social purposes; the material on which one applies work or the object of work; and the means of work or its instrumental elements - should be examined in a connected manner since its reciprocal relationship configures a specific work process ${ }^{(16)}$, as is the case of work performed in the health field(4).

The work process in the health field was influenced by hegemonic models such as Taylorism, the intensive use of cutting-edge technological equipment, and outsourcing ${ }^{(5)}$ of a portion of the workers, among other influences, as also occurred in other fields. However, health practice has its specificities due to its interactive nature - health actions take place within professionalpatient encounters - and its inclusion in the service sector is characterized by intangibility, simultaneity, irreversibility and the impossibility of being stored(17). Such qualities imprint on health work an inherent technical rationality distinct from material production, even though it is also salaried work in private and public organizations ${ }^{(6)}$. Given these characteristics, work performed in health services is considered immaterial, mediated by social relationships and communication, an activity linked to subjectivity ${ }^{(3)}$.

It is important to take into consideration that the term 'subjectivity' leads us to the experience by which we become subjects, singular individuals. However, the existence of an individual takes place from living in society and based on recognition and resistances each individual experiences while in contact with Another, thus the identity of a subject is constructed in each encounter with Another ${ }^{(18)}$. Hence, subjectivity should be associated with a transforming dimension, of continuous reconstruction of identities-in inter-subjectivity ${ }^{(18)}$.

The work performed in the field of health and nursing is mediated by interaction and communication in its daily routine, constituting itself as an essentially inter-subjective human process.

\section{Scientific production in the fields of Collective Health and Nursing based on Marxist theoretical categories and the work process}

The Brazilian theoretical literature addressing labor in the health field indicates, on one hand, was capable of producing an interpretative framework of the various technological arrangements created in the 
field throughout history, as ways of social production and organizing health services, that is, concerning the technological models in health. On the other hand, it shows that there is a large amount of research that departs from the analysis of the activity itself, that is, from the work itself, moving to the analysis of the health workers and their connections with the other agents and subjects participating in the work process - other workers and patients or the population covered by the respective health service ${ }^{(7)}$. "It is apparent that the approach of the two dimensions of the work process in the health field - as productive action and social interaction - permits a dual movement that includes both macro-social aspects, with their crystalized, and for a period of time, permanent structures and the historical configuration of society, and micro-social aspects of subjects - worker-patient and worker-worker - and their interaction dynamics ${ }^{(7)}$.

Two reviews addressing the production of knowledge in the field of Collective Health concerning the theme 'work and health'(11,13), indicate that the relationship between both began in Brazil in the 1970s due to a broadened understanding of the healthdisease continuum introduced by Latin-American Social Medicine. "Under the primacy of the theories of social determination, attention was focused on the relevance of labor in the social reproduction of populations"(13). Research in this period focused on macro-social aspects related to labor: work organization, the market and the workforce. The social and historical aspects that relate to each other in the social context and conform it are named here as macro-social aspects, that is, structural aspects of society.

Only after the 1990 s was this theoretical reference re-dimensioned and adopted into the field of Collective Health to give greater flexibility to the structural determinism and macro-social approach that marked a large part of academic production. Since then, the focus has departed from globalizing explanations, macro theories and meta narratives, and new analytical frameworks have been incorporated focusing on the dynamics of daily social relationships and the understanding of health services at a local level and relationships with the lives of workers and the population using such services ${ }^{(11,13,19)}$.

The valorization of other theoretical strands associated with Marxism from the 1990s on enabled theorists to deepen the inter-subjective dimension of labor. Mendes-Gonçalves and other researchers in Collective Health who adopted classical Marxist concepts started to dialogue with neo-Marxist authors and authors from other philosophical lines such as Gianotti, Heller, Adorno, Habermas, Bachelard and Canguilhem. These authors highlight the dynamic and relational aspects of work in the field of health and requiring consideration of it beyond its structural dimension(10).

Two studies in the nursing field initially analyze the use of the categories 'labor' and 'work process in health'. The first, entitled "Research in Nursing based on work process: in the search for understanding and qualification in Nursing practice"(12), discusses the contributions of Brazilian nursing graduate programs from 1983 to 1997, which use a social interpretation of labor in the field of nursing based on Marx. This study presents a more structural initial reading of labor and it is possible to recognize the dialectics of objectivitysubjectivity based on the analytical categories of other theoretical approaches at the end of the 1990s.

Another study ${ }^{(15)}$ that analyzes Brazilian papers published from 1981 to 2008 addressing the topic 'nursing work' based on Marxist categories. This study highlights the growing number of ways to approach individual subjects, their perceptions and/ or interactions at work, and the approximation of other theoretical frameworks to the understanding of nursing's inclusion in the field of health. Moreover, this study also identifies the analysis of the performance and meanings attributes to the way daily Nursing practice is performed, noting that these topics become more apparent in the 2000s. In this movement, Nursing uses ideas and concepts elaborated by authors such as Michel Foucault, Hannah Arendt, Agnes Heller, Antônio Gramsci, Gregorio Baremblitt, Pierre-Félix Guatarri, Christophe Dejours, Pierre Bourdieu, Jürgen Habermas with some emphasis on authors addressing institutional analysis, the psychodynamics of labor, and the theory of communicative action, among others.

This movement toward deepening understanding of the inter-subjectivity dimension of labor observed in Brazil both in the fields of Collective Health and Nursing, enabled more positive and productive work concerning the dynamic and relational aspects of work in the field of health, which leads to thinking about labor not only as structure of sociability but also as social practice ${ }^{(10)}$.

\section{Inter-subjectivity in health work - contributions from other theoretical sources}

Among other approaches, the Institutional Analysis based on Gilles Deleuze and Félix Guattari; 
the Psychodynamics of Labor by Christophe Dejours; and the theory of Communicative Action by Jürgen Habermas, offer important contributions to the study of the inter-subjectivity of labor in the field of health and nursing allowing us to advance from a more structural reading to an interactional approach.

According to Institutional Analysis, inter-subjectivity is essentially produced by processes that go through the subject, which may be "more territorialized machines" such as ethnics and professional corporation or by industrial processes that operate within the capitalist system $^{(20)}$. These subjective processes can take place through crossings, by a multiplicity of flows ${ }^{(20)}$, thereby establishing health workers and patients as subjects.

Institutional Analysis linked to the Marxist conception of labor, especially to the concept of living and dead labor, configures the analysis of micro-politics of labor in health, with an emphasis on the prominence of subjects in the services' routine. This approach, based on theoretical contributions concerning the technological organization of labor in the field of health by Mendes-Gonçalves ${ }^{(4)}$, unfolds in a typology of health technologies: light, soft-hard and hard(8-9)

The author ${ }^{(8)}$ asserts that health work cannot be totally captured by the logic of dead labor, expressed in equipment and technological knowledge, because its specificities (largely unstructured objects of work, existence of an intercessor space in the health workerpatient relationship, marked relational processes, simultaneity) figure in processes of intervention in action (living work). The work process in the health field essentially occurs with relationship technologies (light technology) in addition to equipment and structured technological knowledge (hard and soft-hard technologies respectively) and involves a significant degree of freedom when one chooses how health actions will be produced(8-9). Hence, we understand that health work is produced in the encounter of subjectivities.

The subject of the Psychodynamics of Labor is included in the field of psychology of labor. Dejour's approach recovers the subjective aspects of labor and its centrality as an element that constitutes an individual and his/her identity ${ }^{(21)}$. Working is a way in which one engages personality to respond to a task delimited by pressure (material and social); it means to fill in a gap between the prescribed and the real ${ }^{(22)}$. Dejour defends the conception of a worker responsible for his/her acts, able to think, interpret the meaning of his/her situation, deliberate, decide, and act based on reason ${ }^{(21)}$.
The author(22) views labor not merely as an activity but a way to a social relation, which means that it unfolds a human world characterized by inequality and power relationships. Working is to engage one's subjectivity in a hierarchical, ordered and coercive world that aims for domination. It is in labor, where one experiences resistance to the social world, that the worker develops intelligence and subjectivity.

These ideas are important to consider the relationships that occur in health work because it is in the relationships that seem to exist as domination through rules and discipline and it is precisely in these relationships in which a greater potential of resistance may exist. Studying the link between subjectivity and inter-subjectivity and labor means to be attentive not only to the relationship of domination that exist in it but also to transgressions, conflicts and the possibility to create other spaces to manage, other ways to deal with norms and even transform them.

Habermas, in his theory of Communicative Actions, states that interaction, work and language constitute a dialectical relationship. Social action occurs in interaction, work and experience of language, and none is more prominent than the others. The practice, essentially communicative, is mediated by language and has an essential role in the socialization and individualization processes. Language, understood as the use of representative symbols, is a substrate required for interaction and work ${ }^{(23)}$.

For the author(23), human actions are guided by three areas of rationality: communicative action, strategic action and instrumental action. Communicative action is actively and explicitly based on agreements rationally motivated by something in the world-a norm, a fact, or subjective experience. This type of action finds a legitimate means for mutual understanding in language. In contrast, in strategic action at least one of the participants seek to produce effects in his/her interlocutors with speech actions, that is, one wants to influence another's behavior to achieve certain unilaterally pursued outcomes. In this case, the subject aims simply to impose a subjective opinion, manipulate other subjects or treat them as means to achieve one's purpose, goals. Another type of action, instrumental action, is based on technical rules and seeks an outcome defined a priori, whose validity depends on statements empirically true or analytically correct.

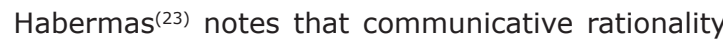
has a single objective, given its essentially dialogical and inter-subjective nature, which is to foster understanding 
among people and produce inter-subjective agreements. It is upon this non-instrumental dimension of rationality that the author bases the construction of his theory of communicative action in which knowledge is produced based on the experience of interaction, language and inter-subjectivity.

Any interaction mediated by language relies on communicative processes since a communicative telos is inherent to language. But in its strong sense, communicative action actively enables its participants to coordinate their actions and construct with their speech actions, while they mutually understand each other, agreements based on a regime of validation that refers to three plans. These are: propositional truth, which expresses the correspondence of what is said with reality so that what is said is inter-subjectively accepted as an expression of facts/things; normative correction, which enables interlocutors to share the statement from an ethical, moral and political point of view; and expressive authenticity, which enables the participants to establish a relationship of mutual recognition, identifying with expressed opinions, intentions, feelings, and desires, authentic manifestations of another's subjectivity ${ }^{(23)}$.

For Habermas ${ }^{(23)}$, the search for the validation of utterances, related to these plans, is based on a formal system of reference that constitutes three distinct worlds: the objective world, the social world and the subjective world, which respectively express the state of things, social norms and the subjectivity of each individual. Communicative action assumes the use of language in all three dimensions, connected by the world of life.

This world in turn presents two facets: continuity and change. Continuity is ensured through cultural reproduction, social integration and socialization. Change occurs in the face of problems, when the validity of inter-subjective agreements concerning the truth of facts, the legitimacy of norms or veracity of subjective manifestations is questioned.

Habermas states that throughout modernity, certain communicative processes that consolidate certain regimes of validity (claims-demands-conditions of validity) stood out from the background of the living world and became empowered as systems and subsystems (scientific, legal, financial, etc.). This movement is characteristic of the modern process of disenchantment and rationalization of world, as theorized by Weber. When these systems and subsystems expanded and became autonomous, they produced what Habermas calls "colonization of the lifeworld", that is, they began to impose an "authority" a priori from its internal logic, creating barriers to the communication processes necessary for a public and free scrutiny of the validity of norms, truths, and subjective experiences of lifeworld, reducing reason to its instrumental dimension(23).

The communicative and instrumental dimensions in the work process in health are not mutually exclusive, rather they should be linked in order to capture and respond to the needs of patients and care delivery. These dimensions are also present in the constitution of agreements among workers and between workers and patients in relation to the way work processes' organization meet such purposes. In this process, as language is used in communicative practice in its strong sense, understanding is enabled among the subjects involved in the action. When understanding is not possible and interaction results in conflict, there is also in this case, in the presence of a communicative action, a greater possibility of coping with and solving problems, that is, the construction and reconstruction of consensus at a local level(24).

Therefore, as previously mentioned, work in the field of health and nursing present dual specificity and is simultaneously a productive action and social interaction that result in care consumed within the act itself. In this dynamics, work as productive action is based on instrumental action grounded in technical rules as rationality directed to purposes-production-but immediately unfolds into social interaction, taking place as communicative action on which understanding among the involved subjects is based on different moments of the work process ${ }^{(7,25)}$.

However, it is worth considering that, in health work, the instrumental and strategic rationalities also invade domains that claim communicative action in the strong sense, since there is a set of health needs that are not recognized and addressed in health care delivery by the technical-scientific rationale or by the fragmented interventions of professionals who act in isolation without taking into account the actions of their colleagues.

In this process, the work agent can either become subordinate to production as an instrument of technique, or act as a subject, as an instituting agent, a protagonist with projects, autonomy and self-government. In this way, in the routine of services, health workers can either reproduce health needs and the way services are organized to meet such needs or create spaces to change in which new needs and their corresponding interventions and ways of work are conceived. Even though the rules of 
work always impose a set of constraints and limitations, health workers are not inevitably doomed to reproduce the work process, they can promote changes based on their work, which involves the technological, interactive and inter-subjective dimensions of the work process ${ }^{(7)}$.

\section{Final considerations}

Recognizing the interactive nature of the work performed in health and nursing implies the need to deeply know and understand the inclusion and participation of service users, the population and workers in the delivery of services and health actions intended to result in integral and decisive care.

Theoretical reflection has revealed the intersubjective relationship that takes place in work, both in health and in nursing, based on three theoretical strands: Institutional Analysis; Psychodynamics of Labor and the Theory of Communicative Action, with an emphasis on the latter.

These strands constitute distinct possibilities that would cover both professional-user interaction and the interaction among professionals are highlighted. It became necessary to link these frameworks to the Marxist approach, especially from the 1990s on, given recognition of the interactive and communicative dimension of the health and nursing work process as well as the theoretical challenges proposed to the historicalsocial approach with an emphasis on the macro-social sphere.

Production in the three different strands reveals contributions concerning the objects of the fields of health and nursing, thus they are not mutually exclusive, rather mutually implicated. However, each of the approaches is based on distinct theoretical foundations and therefore cannot be used interchangeably as they would produce inconsistencies. It is necessary to recognize the potential mediations among them, in how they differ and how they are similar, in addition to giving continuity to its peculiar applications in a way connected to the analysis of health work.

The emphasis given in this study based on these particular theoretical references does not exhaust the possibilities of how to analyze the 'work-intersubjectivity' issue. The existence of other authors and theoretical frameworks with the potential to explain the studied theme has been identified. However, the literature shows a predominance of the discussed strands and the richness of their contributions to reflection on health and nursing their practice in the Brazilian context.

\section{References}

1. Antunes R. O caracol e sua concha: ensaios sobre a nova morfologia do trabalho. São Paulo: Boitempo Editorial; 2005. 136 p.

2. Offe C. Capitalismo desorganizado. São Paulo: Brasiliense; 1995. $322 \mathrm{p}$.

3. Lazzarato M, Negri A. Trabalho imaterial: formas de vida e produção de subjetividade. Rio de Janeiro: DP\&A; 2001. $112 \mathrm{p}$.

4. Mendes-Gonçalves RB. Tecnologia e organização social das práticas de saúde: características tecnológicas do processo de trabalho na rede estadual de Centros de Saúde de São Paulo. São Paulo: Hucitec/Abrasco; 1994. $415 \mathrm{p}$.

5. Pires D. Reestruturação produtiva e trabalho em saúde no Brasil. São Paulo: Annablume; 1998. 254 p.

6. Peduzzi M. Mudanças tecnológicas e seu impacto no processo de trabalho em saúde. Trab Educ Saúde. 2002;1(1) :75-91.

7. Peduzzi M. Trabalho em equipe de saúde da perspectiva de gerentes de serviços de saúde: possibilidades da prática comunicativa orientada pelas necessidades de saúde dos usuários e da população [tese livre-docência]. São Paulo: Escola de Enfermagem da Universidade de São Paulo; 2007. 247 p. [acesso 28 ago. 2011]. Disponível em: http://www.teses.usp. br/teses/disponiveis/livredocencia/7/tde-02072009105425/pt-br.php.

8. Merhy EE. Saúde: a cartografia do trabalho vivo. $3^{a}$ ed. São Paulo: Editora Hucitec; 2002. 189 p. (Saúde em Debate, 145).

9. Merhy EE. Em busca do tempo perdido: a micropolítica do trabalho vivo em saúde. In: Merhy EE, Onocko R. Agir em saúde um desafio para o público. 3a ed. São Paulo (SP): Hucitec; 2007. p. 71-112.

10. Ayres JRCM. Teoria do trabalho e construção de conhecimento em saúde coletiva: para uma epistemologia reconstruída como práxis emancipadora. Divulg Saúde Debate. 1996;(14):13-6.

11. Burlandy L, Bodstein RCA. Política e saúde coletiva: reflexão sobre a produção científica (1976-1992). Cad Saúde Pública. 1998;14(3):543-54.

12. Almeida MCP, Mishima SM, Peduzzi M. A pesquisa em enfermagem fundamentada no processo de trabalho: em busca da compreensão e qualificação da prática de enfermagem. $51^{\circ}$ Congresso Brasileiro de Enfermagem, $10^{\circ}$ Congresso Panamericano de Enfermería; 2-7 outubro 1999; Florianópolis, Santa Catarina. Florianópolis: ABEn; 1999. p. 259-77. 
13. Minayo-Gomez C, Thedim-Costa SMF. Incorporação das ciências sociais na produção de conhecimentos sobre trabalho e saúde. Ciênc Saúde Coletiva. 2003;8(1):125-36.

14. Ramos FRS, Bertoncini JH, Machado RR, Flor RC, Pires DE, Gelbcke FL. Trabalho, educação e política em seus nexos na produção bibliográfica sobre o cuidado. Texto \& Contexto Enferm. 2009;18(2):361-8.

15. Mandú ENT, Peduzzi M, Carvalho BG, Silva AMN. Literatura brasileira sobre o trabalho de enfermagem fundamentada em categorias marxianas. Rev Bras Enferm. 2011 [prelo].

16. Marx K. O capital: crítica da economia política. $14^{a}$ ed. São Paulo: Difel; 1994. 579 p.

17. Meirelles DS. O conceito de serviço. Rev Econ Polit. 2006;26(1):119-36.

18. Ayres JRCM. Sujeito, intersubjetividade e práticas de saúde. Ciênc Saúde Coletiva. 2001;6(1):63-72.

19. Lunardi WD Filho, Lunardi VL, Spricigo J. O trabalho da enfermagem e a produção da subjetividade de seus trabalhadores. Rev. Latino-Am. Enfermagem. 2001;9(2):91-6.

20. Guattari F, Rolnik S. Micropolítica: cartografias do desejo. 7a ed. Petrópolis (RJ): Vozes; 2005. 327 p.

21. Lancman S, Uchida S. Trabalho e subjetividade: o olhar da psicodinâmica do trabalho. Cad Psicol Soc Trab. 2003;6:79-90.

22. Dejours C. Trabalho, subjetividade e ação. Rev Produção. 2004;14(3):27-34.

23. Habermas J. Teoria de la acción comunicativa. I: Racionalidad de la acción y racionalización social. Madrid: Taurus; 2001. 517 p.

24. Artmann E. Interdisciplinaridade no enfoque intersubjetivo habermasiano: reflexões sobre planejamento e AIDS. Ciênc Saúde Coletiva. 2001;6(1):183-95.

25. Peduzzi M. Equipe multiprofissional de saúde: conceito e tipologia. Rev Saúde Pública. 2001;35(1):103-9. 